\title{
Vitamin D Receptor Activators and Clinical Outcomes in Chronic Kidney Disease
}

\author{
Luciana Gravellone, ${ }^{1,2}$ Maria Antonietta Rizzo,, ${ }^{1,2}$ Valentina Martina,, ${ }^{1,2}$ \\ Nicoletta Mezzina, ${ }^{1,2}$ Anna Regalia, ${ }^{2}$ and Maurizio Gallieni, ${ }^{1,2}$ \\ ${ }^{1}$ Specialty School of Nephrology, DMCO, University of Milano Via di Rudini 8, 20142 Milano, Italy \\ ${ }^{2}$ Nephrology and Dialysis Unit, San Carlo Borromeo Hospital, Via Pio II 3, 20153 Milano, Italy \\ Correspondence should be addressed to Maurizio Gallieni, maurizio.gallieni@fastwebnet.it
}

Received 13 March 2011; Accepted 14 March 2011

Academic Editor: Biagio Raffaele Di Iorio

Copyright ( $) 2011$ Luciana Gravellone et al. This is an open access article distributed under the Creative Commons Attribution License, which permits unrestricted use, distribution, and reproduction in any medium, provided the original work is properly cited.

\begin{abstract}
Vitamin D deficiency appears to be an underestimated risk factor for cardiovascular disease in patients with chronic kidney disease. Evidence from both basic science and clinical studies supports the possible protective role of vitamin D beyond its effect on mineral metabolism. Toxicity of pharmacologic doses of active vitamin D metabolites, in particular calcitriol, is mainly due to the possibility of positive calcium and phosphorus balance. Therefore, vitamin D analogs have been developed, which suppress PTH secretion and synthesis with reduced calcemic and phosphatemic effects. Observational studies suggest that in hemodialysis patients the use of a vitamin D receptor (VDR) activator, such as calcitriol, doxercalciferol, paricalcitol, or alfacalcidol, is associated with a reduced mortality when compared with nonusers of any VDR activator. In this article the existing literature on the topic is reviewed, although a more robust answer to the question of whether or not VDR activators have beneficial effects in hemodialysis patients will hopefully come from a randomized controlled trial.
\end{abstract}

\section{Introduction}

Chronic kidney disease (CKD) is associated with increased cardiovascular events and mortality when the glomerular filtration rate declines below $60 \mathrm{~mL} / \mathrm{min} \mathrm{[1-3].} \mathrm{One} \mathrm{signifi-}$ cant event in CKD patients is the development of calcitriol deficiency secondary to the reduction/absence of kidney $\alpha 1$-hydroxylase which mediates the final hydroxylation step of $25(\mathrm{OH})$ vitamin-D to $1,25-(\mathrm{OH})_{2}$ vitamin-D, or calcitriol $[4,5] .1,25-(\mathrm{OH})_{2}$ vitamin-D deficiency causes parathyroid hyperplasia and increased parathyroid hormone [6]; the consequent hyperparathyroidism and hyperphosphatemia are important risk factors for mortality in CKD patients $[4,7]$. Accordingly, vitamin $\mathrm{D}$ treatment is associated with a reduced rate of cardiovascular diseases and mortality $[5,8]$.

Several studies also underline the side effects of calcitriol treatment, such as hypercalcemia and hyperphosphatemia, which carry an increased risk of cardiovascular calcifications. Compared to calcitriol, vitamin D analogs, such as paricalcitol, cause less hypercalcemia and hyperphosphatemia because of less bone resorption and less intestinal absorption $[9,10]$. Calcitriol and vitamin D analogs are better identified as Vitamin D receptor activators.

In addition to suppression of PTH, use of vitamin D receptor activators has been associated with other effects: reduced hospitalization and mortality, prevention of cardiovascular diseases, vascular calcification and atherosclerosis, inhibition of the rennin-angiotensin system, preservation form cellular senescence, improved endothelial function, reduced tubular interstitial fibrosis, and reduced inflammatory status.

Studies about vitamin D receptor activators and clinical outcomes (Table 1) in chronic kidney disease are reviewed in this article.

\section{Materials and Methods}

We researched on PubMed (US National Center for Biotechnology Information) all the articles about "paricalcitol and 
TABLE 1: Vitamin D receptor activators: summary of clinical outcomes.

\begin{tabular}{l}
\hline Suppression of PTH \\
Incidence of hypercalcemia and hyperphosphatemia \\
Mineral metabolism and bone disorder \\
Hospitalization \\
Mortality \\
Cardiovascular protection \\
Prevention of Atheroscleroisis \\
Renal protection and reduction proteinuria \\
Renal protection and renin-angiotensin system \\
Renal protection and tubular interstitial fibrosis \\
Anti-inflammatory effect \\
Cellular senescence \\
Endothelial function
\end{tabular}

outcomes," "doxercalciferol and outcomes," and "maxacalcitol and outcomes" and we found 41 articles: 29 studies on paricalcitol (8 randomized controlled trial, 3 observational studies, 1 open label study, 5 retrospective studies, 1 review, and 10 experimental studies in animals), 4 studies on doxercalciferol ( 3 randomized controlled studies, 1 observational study), 7 studies on maxacalcitol (6 observational studies and 1 experimental study on mice), and 1 experimental study comparing two vitamin D analogs, paricalcitol and doxecalciferol.

\section{Results and Discussion}

\subsection{Suppression of PTH: Effects on Calcium and Phosphate Levels}

3.1.1. Comparing Paricalcitol and Placebo (Table 2). Coyne et al. [11] found that $91 \%$ of patients treated with paricalcitol reached two consecutive PTH level reductions of $30 \%$ or greater versus $13 \%$ of placebo patients $(P<.001)$, while incidences of hypercalcemia, hyperphosphatemia were not significantly different between two groups. Martin et al. [12] demonstrated that $68 \%$ of patients treated with paricalcitol had a 30\% decrease in serum PTH for 4 consecutive weeks-without evidence of hypercalcemia and hyperphosphatemia-versus $8 \%$ of patients treated with placebo $(P<.001)$ (12). Lindberg et al. [13] showed, in an open-label study, that PTH levels fell into target range by month 5 without episodes of hypercalcemia and hyperphosphatemia.

3.1.2. Comparing Paricalcitol and Calcitriol (Table 2). A multicenter, double-blind RCT conducted by Sprague et al. [14] demonstrated that paricalcitol patients have $\geq 50 \%$ and faster reduction in baseline PTH versus calcitriol patients; they also showed that hypercalcemic episodes were $18 \%$ for paricalcitol versus $33 \%$ for calcitriol $(P<.01)$. In a retrospective study, Mittman et al. [15] found that PTH levels were significantly lower for paricalcitol versus calcitriol (247 versus $190 \mathrm{pg} / \mathrm{mL}$ ) while episodes of hypercalcemia and hyperphosphatemia were significantly fewer for paricalcitol versus calcitriol. A crossover study conducted by Coyne et al. [16] demonstrated that suppression of PTH at 36 hours was significantly greater after administration of $160 \mu \mathrm{g}$ of paricalcitol $(63.6 \% \pm 2.3 \%)$ versus calcitriol (but similar after administration of $160 \mu \mathrm{g}$ of paricalcitol), while the increase of serum calcium is greater in calcitriol group. Lund et al. [17] in a single-center, double-blind, activecontrolled, randomized, crossover trial observed that fractional intestinal calcium absorption was significantly lower after paricalcitol versus calcitriol. Finally, Mittman et al. [18] in a 2-year, single-center crossover study demonstrated that conversion from calcitriol to paricalcitol resulted in lower serum calcium $(P<.001)$, lower serum phosphorus $(P<.05)$, reduced PTH $(P=.001)$ and serum alkaline phosphatase $(P<.001)$.

3.1.3. Studies on other VDR Activators, Doxercalciferol, and Maxacalcitol (Tables 3 and 4). In a crossover study comparing paricalcitol and doxercalciferol, Joist et al. [19] observed a similar suppression of $\mathrm{PTH}$, while serum phosphorus was significantly higher using doxercalciferol. In a doubleblind randomized study, Frazão et al. [20], in an openlabel doxercalciferol treatment (16 weeks), and randomized, double-blinded treatment with doxercalciferol or placebo $(8$ weeks), found that $80 \%$ of doxercalciferol patients showed a $70 \%$ reduction in PTH levels from baseline, although serum calcium and phosphate levels increased respectively from 9.2 to $9.7 \mathrm{mg} / \mathrm{dL}$ and from 5.4 to $5.9 \mathrm{mg} / \mathrm{dL}$. Coburn et al. [21] in a randomized, double-blinded, placebo-controlled, multicenter trial in 55 patients with stage 3 or 4 CKD showed that iPTH levels decreased more in doxercalciferol treatment versus placebo $(P<.001)$; no significant differences in mean serum calcium or phosphorus were observed between the two groups. In a randomized study, Zisman et al. [22] demonstrated that in patients on a maintenance dose of paricalcitol, dosing doxercalciferol at $55-60 \%$ of the paricalcitol dose results in comparable inhibition of $\mathrm{PTH}$, with similar incidences of hypercalcemia and hyperphosphatemia. Comparing maxacalcitol and calcitriol, Hayashi et al. [23] found no significant differences between the two groups in serum iPTH and phosphorus concentration, while serum calcium was significantly higher in the maxacalcitol versus calcitriol group during early treatment, but not at the end of treatment. Shiizaki et al. [24], in a study conducted in $5 / 6$ nephrectomized rats treated by a direct injection of maxacalcitol into the parathyroid gland, found a significant decrease of PTH versus rats treated by vehicle, along with upregulation of both VDR and CaSR in the parathyroid tissue; no differences in calcium and phosphorus levels were observed between two groups. Kazama et al. [25] found that both maxacalcitol and calcitriol significantly decreased plasma intact PTH levels and increased serum Ca levels, but PTH levels were significantly lower in the maxacalcitol group after 24 weeks of treatment. In addition, serum phosphate levels were significantly higher in the calcitriol group. Thus, these authors proposed maxacalcitol as a possible less phosphatemic active vitamin $\mathrm{D}$ agent which might reduce the risk 
TABLE 2: Suppression of PTH and effects on calcium and phosphate levels: paricalcitol versus placebo and paricalcitol versus calcitriol.

\begin{tabular}{|c|c|c|c|c|}
\hline Author & Year & Study & Outcome 1 & Outcome 2 \\
\hline Coyne et al. [11] & 2006 & $\begin{array}{l}\text { Three randomized, } \\
\text { placebo-controlled, phase- } 3 \text { trials } \\
\text { were conducted in } 220 \text { patients } \\
\text { with stage } 3 \text { and } 4 \text { CKD with } \\
\text { secondary hyperparathyroidism. } \\
\text { 24-week studies }\end{array}$ & $\begin{array}{l}\text { Decreases in PTH levels of } 30 \% \\
\text { or greater in } 91 \% \text { of paricalcitol } \\
\text { versus } 13 \% \text { of placebo patients } \\
(P<.001)\end{array}$ & $\begin{array}{l}\text { Incidences of hypercalcemia, } \\
\text { hyperphosphatemia, and } \\
\text { elevated } \mathrm{Ca} \times \mathrm{P} \text { were not } \\
\text { significantly different between } \\
\text { groups }\end{array}$ \\
\hline Martin et al. [12] & 1998 & $\begin{array}{l}3 \text { double-blind RCTs } \\
n=78 \text { dialysis patients } 12 \text {-week } \\
\text { study }\end{array}$ & $\begin{array}{l}27 \text { of } 40 \text { patients receiving } \\
\text { paricalcitol }(68 \%) \text { had a } 30 \% \\
\text { decrease in serum PTH for } 4 \\
\text { consecutive weeks, versus } 3 \text { of } 38 \\
\text { patients }(8 \%) \text { receiving placebo } \\
(P<.001)\end{array}$ & $\begin{array}{l}\text { No evidence of hypercalcemia } \\
\text { and hyperphosphatemia }\end{array}$ \\
\hline Lindberg et al. [13] & 2001 & $\begin{array}{l}\text { Open-label study } \\
n=164 \text { dialysis patients. } \\
13 \text {-month study }\end{array}$ & $\begin{array}{l}\text { Mean PTH levels fell into target } \\
\text { range }(100-300 \mathrm{pg} / \mathrm{mL}) \text { by } \\
\text { month } 5\end{array}$ & $\begin{array}{l}\text { Serum calcium and phosphorus } \\
\text { were in normal range }\end{array}$ \\
\hline Sprague et al. [14] & 2003 & $\begin{array}{l}\text { Multicenter, double-blind RCT; } \\
n=263 \text { dialysis patients. } \\
\text { 32-week study }\end{array}$ & $\begin{array}{l}\text { Paricalcitol patients had a } \geq 50 \% \\
\text { and faster reduction in baseline } \\
\text { PTH versus calcitriol patients ( } 87 \\
\text { versus } 107 \text { days). Paricalcitol } \\
\text { patients reached a therapeutic } \\
\text { PTH range in } 18 \text { weeks versus } \\
\text { calcitriol patients who never } \\
\text { reached the target range }\end{array}$ & $\begin{array}{l}\text { Hypercalcemic episodes were } \\
18 \% \text { for paricalcitol versus } 33 \% \\
\text { for calcitriol }(P=.008)\end{array}$ \\
\hline Mittman et al. [15] & 2004 & $\begin{array}{l}\text { Retrospective study } \\
n=101 \text { dialysis patients } \\
24 \text {-month study }\end{array}$ & $\begin{array}{l}\text { PTH levels were significantly } \\
\text { lower for paricalcitol versus } \\
\text { calcitriol ( } 247 \text { versus } 190 \mathrm{pg} / \mathrm{mL} \text { ) }\end{array}$ & $\begin{array}{l}\text { Number of hypercalcemic } \\
\text { episodes were } 111 \text { for paricalcitol } \\
\text { versus } 69 \text { for calcitriol; number } \\
\text { of episodes of } \\
\text { hyperphosphatemia were } 225 \text { for } \\
\text { paricalcitol versus } 186 \text { for } \\
\text { calcitriol }\end{array}$ \\
\hline Coyne et al. [16] & 2002 & $\begin{array}{l}\text { Crossover study } \\
n=10 \text { dialysis patients } 36 \text {-hour } \\
\text { study }\end{array}$ & $\begin{array}{l}\text { Suppression of PTH at } 36 \text { hours } \\
\text { was significantly greater after } \\
\text { administration of } 160 \mu \mathrm{g} \text { of } \\
\text { paricalcitol }(63.6 \% \pm 2.3 \%) \\
\text { versus calcitriol }\end{array}$ & $\begin{array}{l}\mathrm{Ca} \times \mathrm{P} \text { product increased more } \\
\text { after calcitriol administration } \\
\text { than after a } 6 \text { - or } 8 \text {-fold greater } \\
\text { dose of paricalcitol }\end{array}$ \\
\hline Lund et al. [17] & 2010 & $\begin{array}{l}\text { Single-center, double-blind, } \\
\text { active-controlled, randomized, } \\
\text { crossover trial. } n=22 \\
\text { hemodialysis patients }\end{array}$ & $\begin{array}{l}\text { Fractional intestinal calcium } \\
\text { absorption was significantly } \\
\text { lower after paricalcitol }(0.135 \pm \\
0.006) \text { versus calcitriol }(0.158 \pm \\
0.006, P=.022)\end{array}$ & \\
\hline Mittman et al. [18] & 2010 & $\begin{array}{l}2 \text {-year, single-center crossover } \\
\text { study } \\
n=73 \text { hemodialysis patients } \\
\text { converted from calcitriol to } \\
\text { paricalcitol using a } 1: 3 \\
\text { conversion ratio }\end{array}$ & $\begin{array}{l}\text { Conversion from calcitriol to } \\
\text { paricalcitol resulted in lower } \\
\text { serum calcium }(P<.001) \text {, lower } \\
\text { serum phosphorus }(P<.05) \text {, } \\
\text { reduced PTH }(P=.001) \text { and } \\
\text { reduced serum alkaline } \\
\text { phosphatase }(P<.001)\end{array}$ & \\
\hline
\end{tabular}

of extraskeletal calcification [25]. Oyama et al. [26] treated patients with maxacalcitol intravenously and found that lower pretreatment plasma iPTH and calcium levels, but not phosphorus levels, were predictor of the response to treatment with maxacalcitol. On the other hand, serum levels of phosphorus did not significantly increase during treatment.

3.1.4. Parathyroid Hyperplasia (Table 5). Several studies addressed the issue of parathyroid hyperplasia (Table 5).
Okuno et al. [27] demonstrated that the responsiveness to maxacalcitol therapy of secondary hyperparathyroidism is dependent on parathyroid gland size and that the simple measurement of maximum parathyroid gland diameter by ultrasonography may be useful for predicting responsiveness to maxacalcitol treatment. They suggest that glands larger than $11 \mathrm{~mm}$ do not adequately respond to treatment. Shiizaki et al. [28] also studied 20 patients with SHPT and enlarged parathyroid glands treated by percutaneous maxacalcitol 
TABLE 3: Suppression of PTH and effects on calcium and phosphate levels: doxercalciferol versus placebo and doxercalciferol versus paricalcitol.

\begin{tabular}{|c|c|c|c|c|}
\hline Author & Year & Study & Outcome 1 & Outcome 2 \\
\hline Joist et al. [19] & 2006 & $\begin{array}{l}\text { Crossover study } \\
n=13 \text { dialysis patients } 36 \text {-hour } \\
\text { study paricalcitol versus } \\
\text { doxercalciferol }\end{array}$ & $\begin{array}{l}\text { Clinical suppression of PTH at } \\
36 \text { hours was comparable } \\
\text { between treatment arms ( } 63 \% \\
\text { following paricalcitol therapy } \\
\text { and } 65 \% \text { following } \\
\text { doxercalciferol therapy). }\end{array}$ & $\begin{array}{l}\text { Serum phosphorus was } \\
\text { significantly higher during } \\
\text { administration of doxercalciferol } \\
(2.12 \pm 0.11 \mathrm{mmol} / \mathrm{L} \text { versus } 1.85 \\
\pm 0.07 \mathrm{mmol} / \mathrm{L}) .\end{array}$ \\
\hline Frazão et al. [20] & 2000 & $\begin{array}{l}\text { Double-blind, RCT } \\
n=99 \text { dialysis patients } 8 \text {-week } \\
\text { study }\end{array}$ & $\begin{array}{l}80 \% \text { of doxercalciferol patients } \\
\text { showed a } 70 \% \text { reduction in PTH } \\
\text { levels from baseline, and } 83 \% \text { of } \\
\text { the doxercalciferol patients met } \\
\text { the study PTH targets. }\end{array}$ & $\begin{array}{l}\text { During double-blinded } \\
\text { treatment, } 3.26 \% \text { and } 0.46 \% \text { of } \\
\text { [Ca] measurements exceeded } \\
11.2 \mathrm{mg} / \mathrm{dl} \text { with doxercalciferol } \\
\text { and placebo, respectively. }\end{array}$ \\
\hline Coburn et al. [21] & 2004 & $\begin{array}{l}\text { RCT, } n=55 \text { patients with stage } 3 \\
\text { or } 4 \text { CKD treated with } \\
\text { doxercalciferol versus placebo. }\end{array}$ & $\begin{array}{l}\text { Mean plasma iPTH level } \\
\text { decreased by } 46 \% \text { from baseline } \\
\text { after } 24 \text { weeks of doxercalciferol } \\
\text { treatment }(P<.001) \text {, versus } \\
\text { placebo. After } 6 \text { weeks, iPTH } \\
\text { level decreased with } \\
\text { doxercalciferol versus placebo } \\
(P<.001) .\end{array}$ & $\begin{array}{l}\text { No significant differences in } \\
\text { mean serum calcium or } \\
\text { phosphorus between the groups. }\end{array}$ \\
\hline Zisman et al. [22] & 2005 & $\begin{array}{l}\text { RCT, } n=27 \text { hemodialysis } \\
\text { patients randomized to receive } \\
\text { doxercalciferol at either } 35,50 \text {, or } \\
65 \% \text { of the paricalcitol dose for } 6 \\
\text { weeks }\end{array}$ & $\begin{array}{l}\text { A conversion factor of } 0.57 \text { for } \\
\text { the dose of doxercalciferol } \\
\text { relative to paricalcitol resulted in } \\
\text { equivalent suppression of iPTH }\end{array}$ & $\begin{array}{l}\text { Incidences of hypercalcemia and } \\
\text { hyperphosphatemia were similar } \\
\text { for all groups }\end{array}$ \\
\hline
\end{tabular}

TABLE 4: Suppression of PTH and effects on calcium and phosphate levels: maxacalcitol versus placebo and maxacalcitol versus calcitriol.

\begin{tabular}{|c|c|c|c|c|}
\hline Author & Year & Study & Outcome 1 & Outcome 2 \\
\hline $\begin{array}{l}\text { Hayashi et al. } \\
{[23]}\end{array}$ & 2004 & $\begin{array}{l}n=91 \text { patients } \\
47 \text { patients treated with calcitriol } \\
\text { versus } 44 \text { patients treated with } \\
\text { maxacalcitol for } 12 \text { months }\end{array}$ & $\begin{array}{l}\text { There were no significant } \\
\text { differences between the two groups } \\
\text { in serum iPTH }\end{array}$ & $\begin{array}{l}\text { No significant differences between } \\
\text { the two groups in phosphorus } \\
\text { concentration. } \\
\text { Serum calcium was significantly } \\
\text { higher in the maxacalcitol versus } \\
\text { calcitriol group during early } \\
\text { treatment, but not at the end of } \\
\text { treatment }\end{array}$ \\
\hline $\begin{array}{l}\text { Shiizaki et al. } \\
{[24]}\end{array}$ & 2005 & $\begin{array}{l}\text { Uremic }(5 / 6 \mathrm{NX}) \text { rats fed a } \\
\text { high-phosphate diet and treated by } \\
\text { a direct injection of } \\
\text { maxacalcitol-OCT (DI-OCT) or } \\
\text { vehicle (DI-vehicle) }\end{array}$ & $\begin{array}{l}\text { DI-OCT decreased PTH levels with } \\
\text { a significant difference DI-OCT } \\
\text { versus DI-vehicle. } \\
\text { Upregulations of both VDR and } \\
\text { CaSR after DI-OCT were observed } \\
\text { versus DI-vehicle-treated rats. }\end{array}$ & $\begin{array}{l}\text { Serum calcium and phosphorus } \\
\text { levels did not changed markedly in } \\
\text { both groups }\end{array}$ \\
\hline $\begin{array}{l}\text { Kazama et al. } \\
{[25]}\end{array}$ & 2005 & $\begin{array}{l}n=126 \text { nondiabetic hemodialysis } \\
\text { patients with PTH levels greater } \\
\text { than } 300 \mathrm{pg} / \mathrm{mL} \text { treated with either } \\
\text { maxacalcitol }(n=80) \text { or calcitriol } \\
(n=46) \text { for } 24 \text { weeks. }\end{array}$ & $\begin{array}{l}\text { Both treatments decreased plasma } \\
\text { intact PTH levels }(P<.0001) \text { and } \\
\text { increased serum Ca levels } \\
(P<.0001) \text {. PTH levels were } \\
\text { significantly lower in the } \\
\text { maxacalcitol group after } 24 \text { weeks } \\
(P<.01) .\end{array}$ & $\begin{array}{l}\text { Serum phosphate was significantly } \\
\text { greater in the calcitriol group } \\
(P<.05)\end{array}$ \\
\hline $\begin{array}{l}\text { Oyama et al. } \\
{[26]}\end{array}$ & 2005 & $\begin{array}{l}\text { Nondiabetic dialysis patients } \\
(n=146) \text { with iPTH levels } \\
>300 \mathrm{pg} / \mathrm{mL} \text { were treated with i.v. } \\
\text { maxacalcitol injected } 3 / \text { week for } 48 \\
\text { weeks. }\end{array}$ & $\begin{array}{l}96 \text { patients were successfully treated } \\
\text { (iPTH levels }<300 \mathrm{pg} / \mathrm{ml} \text { within } 48 \\
\text { weeks). Pretreatment PTH and Ca } \\
\text { levels were lower in patients } \\
\text { successfully treated with } \\
\text { maxacalcitol. }\end{array}$ & $\begin{array}{l}\text { Serum phosphorus levels did not } \\
\text { significantly increase. } \\
\text { Phosphorus levels were not } \\
\text { predictive of the response to } \\
\text { treatment with maxacalcitol. }\end{array}$ \\
\hline
\end{tabular}


TABle 5: Parathyroid hyperplasia.

\begin{tabular}{|c|c|c|c|}
\hline Author & Year & Study & Outcome \\
\hline Okuno et al. [27] & 2003 & $\begin{array}{l}n=25 \text { patients treated with maxacalcitol }(\mathrm{PTH} \\
>300 \mathrm{pg} / \mathrm{ml} \text {; mean maximal diameter of } \\
\text { parathyroid glands } 11.0 \pm 0.7 \mathrm{~mm} \text { before } \\
\text { treatment }) \text {, divided in two groups: } \\
\text { group } S \text { gland diameter }<11.0 \mathrm{~mm} \text { versus } \\
\text { group L with gland diameter }>11.0 \mathrm{~mm} . \\
\text { Parathyroid volume was measured by } \\
\text { ultrasonography. }\end{array}$ & $\begin{array}{l}\text { At } 4-24 \text { weeks after administration of } \\
\text { maxacalcitol, intact PTH concentrations } \\
\text { decreased significantly in group } S(P<.01) \text {, } \\
\text { versus group L. } \\
\text { Serum calcium increased significantly in group } \\
\mathrm{L}(P<.05) \text {, versus group S. } \\
\text { Glands larger than } 11 \mathrm{~mm} \text { do not adequately } \\
\text { respond to treatment. }\end{array}$ \\
\hline Shiizaki et al. [28] & 2003 & $\begin{array}{l}n=20 \text { patients with SHPT and enlarged } \\
\text { parathyroid glands were treated by } \\
\text { percutaneous maxacalcitol injection therapy } \\
\text { (PMIT) under ultrasonographic guidance } \\
\text { consecutively } 6 \text { times, followed by i.v. } \\
\text { maxacalcitol. }\end{array}$ & $\begin{array}{l}\text { PMIT and subsequent i.v. maxacalcitol } \\
\text { administration significantly decreased PTH } \\
\text { levels and parathyroid gland volume for at least } \\
12 \text { weeks. }\end{array}$ \\
\hline Akizawa and Kurokawa [29] & 2002 & $\begin{array}{l}\text { A trial on the long-term administration of } \\
\text { maxacalcitol ( } 3 \text { times weekly for } 26 \text { weeks } \\
\text { subsequent to a } 26 \text {-week pretrial) in } 124 \\
\text { dialysis patients with secondary } \\
\text { hyperparathyroidism. }\end{array}$ & $\begin{array}{l}\text { PTH levels fell promptly and significantly and } \\
\text { were well controlled for one year. Serum } \\
\text { calcium levels rose significantly, but within a } \\
\text { physiological range. Hypercalcemia }(33.1 \%) \\
\text { was resolved or ameliorated after the } \\
\text { withdrawal or dose reduction of maxacalcitol. }\end{array}$ \\
\hline Saito et al. [30] & 2010 & $\begin{array}{l}\text { An outpatient treatment regimen using } \\
\text { percutaneous maxacalcitol injection therapy } \\
\text { (PMIT) on a weekly basis for } 4-6 \text { weeks } \\
\text { following dialysis. }\end{array}$ & $\begin{array}{l}\text { Intact PTH decreased from } 797 \text { to } 253 \mathrm{pg} / \mathrm{mL} \text {. } \\
\text { Ultrasonographic examination detected a } \\
\text { gradual reduction in parathyroid gland volume } \\
\text { from } 1.27 \text { to } 0.24 \mathrm{~cm}^{3} \text {. }\end{array}$ \\
\hline
\end{tabular}

TABLE 6: Mineral metabolism and bone disorder.

\begin{tabular}{|c|c|c|c|}
\hline Author & Year & Study & Outcome \\
\hline Slatopolsky et al. [31] & 2003 & $\begin{array}{l}\text { A study in uremic rats to assess } \\
\text { the efficacy of paricalcitol in } \\
\text { prevention (protocol I) and } \\
\text { treatment (protocol II) of } \\
\text { hyperparathyroidism and renal } \\
\text { osteodystrophy. }\end{array}$ & $\begin{array}{l}\text { Paricalcitol was effective in } \\
\text { preventing (protocol I) and } \\
\text { suppressing (protocol II) the } \\
\text { significant hyperparathyroidism } \\
\text { induced by uremia and enhanced } \\
\text { by a high phosphorus diet; it } \\
\text { improved bone histology in } \\
\text { uremic rats affected by severe } \\
\text { secondary hyperparathyroidism. }\end{array}$ \\
\hline Kazama et al. [32] & 2005 & $\begin{array}{l}N=50 \text { chronic dialysis patients } \\
\text { with PTH levels }>300 \mathrm{pg} / \mathrm{mL} \\
\text { treated with } 10 \mu \mathrm{g} \text { of i.v. } \\
\text { maxacalcitol thrice a week. }\end{array}$ & $\begin{array}{l}\text { PTH, bone-specific alkaline } \\
\text { phosphatase and osteocalcin } \\
\text { levels were significantly lowered; } \\
\text { serum calcium levels increased. } \\
\text { Osteoprotegerin levels } \\
\text { significantly decreased } \\
(P<.0001) \text {. }\end{array}$ \\
\hline
\end{tabular}

injection therapy, which significantly decreased the serum intact-PTH level and parathyroid gland volume for at least 12 weeks. Akizawa and Kurokawa [29], in a trial on the longterm administration of maxacalcitol, found that PTH levels fell promptly and were well controlled for one year, with doses ranging from 2.5 to $20 \mathrm{mg}$ per dialysis. Serum calcium levels rose significantly, but within a physiological range; episodes of hypercalcemia were present in 33\% of patients. Saito et al. [30] proposed an outpatient treatment regimen using percutaneous maxacalcitol injection therapy on a weekly basis for 4-6 weeks following dialysis. They found no major complications and intact parathyroid hormone decreased from $797 \pm 178 \mathrm{pg} / \mathrm{mL}$ to $253 \pm 25 \mathrm{pg} / \mathrm{mL}$, while the parathyroid gland volume gradually decreased from 1.27 $\pm 1.06 \mathrm{~cm}^{3}$ to $0.24 \pm 0.15 \mathrm{~cm}^{3}$.

3.2. Vitamin D Receptor Activators, Mineral Metabolism, and Bone Disorders (Table 6). Activation of the vitamin D receptor plays a role in bone metabolism and treatment with VDR activators may favorably affect bone disease. Slatopolsky et al. [31] studied uremic rats to assess the efficacy of paricalcitol in prevention and treatment of renal osteodystrophy. Paricalcitol resulted effective in preventing and suppressing hyperparathyroidism induced by uremia and enhanced by 
TABLE 7: Hospitalization and mortality.

\begin{tabular}{|c|c|c|c|}
\hline Author & Year & Study & Outcome \\
\hline Dobrez et al. [33] & 2004 & $\begin{array}{l}\text { Data from January } 1999 \text { to November } 2001 ; \\
n=11443 \text { hemodialysis patients who } \\
\text { received at least } 10 \text { doses of vitamin D } \\
\text { therapy }\end{array}$ & $\begin{array}{l}\text { The paricalcitol group had a lower risk of first all-cause } \\
\text { hospitalization }(14 \% \text { less, } P<.0001) \text {, fewer } \\
\text { hospitalizations per year }(0.642 \text { fewer, } P<.001) \text { and } \\
\text { fewer hospital days per year }(6.84 \text { fewer, } P<.001) \\
\text { versus calcitriol }\end{array}$ \\
\hline Vervloet et al. [34] & 2009 & $\begin{array}{l}\text { A review of observational studies that } \\
\text { examined the association between the use of } \\
\text { VDRA and mortality }\end{array}$ & $\begin{array}{l}\text { Hospitalization is less frequent in patients treated with } \\
\text { paricalcitol versus patients treated with calcitriol }\end{array}$ \\
\hline Teng et al. [35] & 2003 & $\begin{array}{l}\text { A historical cohort study to compare the } \\
36 \text {-month survival rate among dialysis } \\
\text { patients receiving treatment with } \\
\text { paricalcitol ( } 29,021 \text { patients) versus } \\
\text { calcitriol ( } 38,378 \text { patients). }\end{array}$ & $\begin{array}{l}\text { The mortality rate among patients receiving paricalcitol } \\
\text { was } 0.180 \text { per person-year versus } 0.223 \text { per person-year } \\
\text { among those receiving calcitriol }(P<.001) \text {. The } \\
\text { difference in survival was significant at } 12 \text { months and } \\
\text { increased with time. In the adjusted analysis, the } \\
\text { mortality rate was } 16 \text { percent lower }(95 \% \mathrm{CI}, 10 \text { to } 21 \\
\text { percent) among paricalcitol-treated patients than } \\
\text { among calcitriol-treated patients. } \\
\text { At } 12 \text { months, calcium and phosphorus levels had } \\
\text { increased by } 6.7 \text { and } 11.9 \text { percent, respectively, in the } \\
\text { paricalcitol group, as compared with } 8.2 \text { and } 13.9 \\
\text { percent, respectively, in the calcitriol group }(P<.001) \text {. }\end{array}$ \\
\hline Tentori et al. [36] & 2006 & $\begin{array}{l}n=7731 \text { patients (calcitriol: } n=3212 ; \\
\text { paricalcitol: } n=2087 \text {; doxercalciferol: } \\
n=2432 \text { ) in the years 1999-2004. Median } \\
\text { follow-up was } 37 \text { weeks. }\end{array}$ & $\begin{array}{l}\text { Mortality rates (deaths/100 patient-years) were } \\
\text { identical in patients treated with doxercalciferol }(15.4 \text {, } \\
95 \% \text { CI } 13.6-17.1) \text { and paricalcitol }(15.3,13.6-16.9) \\
\text { and higher in patients on calcitriol }(19.6,18.2-21.1) \\
(P<.0001) \text {. Overall, mortality was higher for patients } \\
\text { who did not receive vitamin D versus those who did. }\end{array}$ \\
\hline
\end{tabular}

a high phosphorus diet. In addition paricalcitol ameliorated the histomorphometric changes induced by uremia and high phosphorus diet, improving bone histology in uremic rats affected by severe secondary hyperparathyroidism. Kazama et al. [32] treated 50 patients with hyperparathyroidism (serum PTH $>300 \mathrm{pg} / \mathrm{mL}$ ) with $10 \mu \mathrm{g}$ of maxacalcitol intravenously injected thrice a week. They observed, along with a reduction of PTH levels, a significant decrease of bone-specific alkaline phosphatase and osteoprotegerin levels. Osteoprotegerin is a natural glycoprotein which plays a critical role in osteoclast physiology. Elevated levels of circulating osteoprotegerin may account for the development of bone and mineral metabolic abnormalities in uremia.

3.3. Hospitalization and Mortality (Table 7). There are studies which demonstrate that VDR activators are able to reduce hospitalization and mortality. Dobrez et al. [33] observed in 11443 hemodialysis patients receiving at least 10 doses of vitamin $\mathrm{D}$ therapy that paricalcitol group had a lower risk of first all-cause hospitalization (14\% less, $P<.0001)$, fewer hospitalizations per year $(0.642$ fewer, $P<.001)$, and fewer hospital days per year $(6.84$ fewer, $P<.001)$ versus calcitriol. Vervloet and Twisk [34] analyzed the observational studies on the association between use of VDR activators and mortality. They underscored the absence of randomized controlled trials but considered the available observational studies "quite robust and consistent". The hypothesis of a positive, clinically significant effect of treatment with VDR activators is supported by the presence of plausible mechanisms that might explain their observed benefit in patients on dialysis, beyond their classic role in bone and mineral metabolism. Specifically, these include inhibition of renin biosynthesis, modulation of arterial function, positive effects on left ventricular hypertrophy, attenuation of insulin resistance, potential positive impact on immune function, reduced incidence of cancer, and other potential mechanisms [34]. A seminal study on the possible relationship between paricalcitol treatment and reduced mortality was published by Teng et al. [35]. They designed a historical cohort study to compare the 36-month survival rate among hemodialysis patients receiving treatment with paricalcitol versus calcitriol: mortality rate among patients receiving paricalcitol was significantly lower versus patients receiving calcitriol $(P<.001)$. Tentori et al. [36], conduced on 7731 patients to compare calcitriol, paracaclcitol and doxercalciferol. They demonstrated that mortality rates were similar in patients treated with doxercalciferol and paricalcitol, while higher in patients treated with calcitriol $(P<.001)$. Thus, the survival benefit in chronic kidney disease patients, independent of the effects on parathyroid hormone and calcium levels, appears to be better with the use of vitamin D analogs (paricalcitol and doxercalciferol), followed by the use of calcitriol, and the worst survival is associated with no VDR activation therapy. The mechanisms underlying the cardiovascular and survival benefit of VDR activators are still under active investigation. Several different potential factors could play a role, as VDR has been identified in more than 30 different tissues in the human body, including the vasculature [8]. 
TABLE 8: Cardiovascular protection.

\begin{tabular}{lll}
\hline Author & Year & Study \\
\hline & & \\
& 2007 & $\begin{array}{l}\text { Study in Dahl salt-sensitive (DSS) rats to } \\
\text { evaluate if paricalcitol is able to attenuate the } \\
\text { development of left ventricular abnormalities }\end{array}$
\end{tabular}

Outcome

Compared with DSS rats fed a high-salt (HS)

diet $(6 \% \mathrm{NaCl}$ for 6 weeks), DSS rats fed a

high-salt HS receiving paricalcitol showed

lower heart and lung weights, reduced LV

mass, posterior wall thickness and end diastolic

pressures, and increased fractional shortening.

Blood pressures did not significantly differ

between the groups

In VDRKO mice, the cardiac renin mRNA level was significantly increased, suggesting that the

cardiac hypertrophy in VDRKO mice is a

consequence of activation of both the systemic and cardiac RAS and that

1,25-dihydroxyvitamin $\mathrm{D}_{3}$ regulates cardiac functions

Ablation of the lalpha-hydroxylase gene in mice led to hypertension, cardiac hypertrophy, and systolic dysfunction, and this cardiac

25(OH)D lalpha-hydroxylase $\mathrm{KO}$ mice were

Zhou et al. [39]

2008 compared with WT mice to determine whether the cardiovascular effect of $1,25 \mathrm{vitD}$ is dependent on calcium or phosphorus. phenotype was rescued with exogenous

1,25 vitD administration. 1,25vitD plays a protective role in the cardiovascular system by repressing the renin-angiotensin system independent of extracellular calcium or phosphorus.

RCT, oral paricalcitol compared to placebo in 220 predialysis patients (GFR $15-45 \mathrm{ml} / \mathrm{min}$ ) affected by mild-to-moderate LVH and an LV ejection fraction $>50 \%$
PRIMO study (Paricalcitol Benefits in Renal Disease Induced Cardiac Morbidity Ongoing Study) [40] Mizobuchi et al. [41] 2007
Uremic rats (5/6 NX rats) were given calcitriol, paricalcitol, or doxercalciferol 3/week for 1 month

\section{Study ongoing}

Calcitriol and doxercalciferol, but not paricalcitol, increased vascular calcification in uremic rats. The different effects of VDRA on vascular calcification are independent of an effect on Ca and P. Doxercalciferol significantly increased the $\mathrm{Ca} \times \mathrm{P}$ product and the aortic calcium content. A lower doxercalciferol did not increase the calcium-phosphate product but increased the aortic calcium content.
3.4. Cardiovascular Protection (Table 8). One hypothesis derived from the available observational studies suggests that systemic activation of VDRs may have direct effects on the cardiovascular system to decrease mortality in patients with chronic kidney disease [8]. Vitamin D and its analogs may play a role in preserving the cardiovascular system and reducing vascular calcification. In accordance with this concept, Levin and $\mathrm{Li}$ [54] suggested that Vitamin $\mathrm{D}$ deficiency might be an underestimated risk factor for cardiovascular disease in chronic kidney disease. They also underscore that evidence from both basic science and clinical studies supports the possible protective role of vitamin D beyond its effect on mineral metabolism. Bodyak et al. [37] studied Dahl salt-sensitive rats fed a high-salt diet $(6 \% \mathrm{NaCl}$ for 6 weeks) and receiving paricalcitol, showing lower heart and lung weights, reduced left ventricular mass, posterior wall thickness and end diastolic pressures, and increased fractional shortening. Xiang et al. [38] studied VDR knockout mice and they showed that cardiac renin
mRNA levels were significantly increased, suggesting that the cardiac hypertrophy in VDR knock-out mice is a consequence of the activation of both the systemic and cardiac rennin angiotensin system and that 1,25-dihydroxyvitamin $\mathrm{D}_{3}$ regulates cardiac functions. In another gene knock-out study by Zhou et al. [39], ablation of the 1alpha-hydroxylase gene in mice led to hypertension, cardiac hypertrophy, and systolic dysfunction, and this cardiac phenotype was rescued with exogenous 1,25-dihydroxyvitamin D administration. The authors concluded that calcitriol plays a protective role in the cardiovascular system by repressing the reninangiotensin system independent of extracellular calcium or phosphorus. In humans, the PRIMO study (Paricalcitol Capsules Benefits in Renal Failure Induced Cardiac MOrbidity Study), a multinational, randomized, double-blinded trial with oral paricalcitol compared to placebo, is ongoing [40]: its primary outcome measure is to investigate the effects of paricalcitol on progression or regression of left ventricular hypertrophy in Stage 3B/4 chronic kidney disease subjects, 
TABLE 9: Prevention of atherosclerosis.

\begin{tabular}{llll}
\hline Author & Year & Study & Outcome \\
\hline & & $\begin{array}{l}\text { A study in atherosclerotic mice to investigate the } \\
\text { protective effect of paricalcitol combined with } \\
\text { angiotensin-converting enzyme inhibitor (enalapril) } \\
\text { on aortic oxidative injury }\end{array}$ & $\begin{array}{l}\text { ApoE-deficient mice developed hypertension which } \\
\text { was prevented by enalapril or enalapril + paricalcitol } \\
\text { treatment (not by paricalcitol alone). Atherosclerotic } \\
\text { plaque in the aorta of ApoE-deficient mice was } \\
\text { prevented by paricalcitol, enalapril, and paricalcitol } \\
\text { + enalapril treatments }\end{array}$ \\
\hline
\end{tabular}

through the evaluation of changes in left ventricular mass index, in a time frame of 48 weeks.

Mizobuchi et al. [41] studied uremic rats treated with calcitriol, paricalcitol, or doxercalciferol and found that calcitriol and doxercalciferol, but not paricalcitol, increase vascular calcification in uremic rats; in particular the different effects of VDR activators on vascular calcification appear to be independent of serum calcium and phosphate levels.

3.5. Prevention of Atheroscleroisis (Table 9). Husain et al. [42] conducted a study in atherosclerotic mice to investigate the protective effect of paricalcitol combined with angiotensinconverting enzyme inhibition (by enalapril) on aortic oxidative injury. They found that ApoE-deficient mice developed hypertension, which was prevented by enalapril or by the combined enalapril and paricalcitol treatment, but not by paricalcitol alone. On the other hand, atherosclerotic plaque in the aorta of ApoE-deficient mice was prevented by paricalcitol, enalapril, and paricalcitol + enalapril treatments. Combination therapy afforded greater protection against aortic inflammatory and oxidative injury in atherosclerosis than monotherapy. This observation underscores the role of VCR activators not only as PTH suppressors but also as an essential treatment in patients with chronic kidney diseases, which are notoriously more exposed to cardiovascular diseases and atherosclerosis.

3.6. Renal Protection and Reduction of Proteinuria (Table 10). Agarwal et al. [43] in three double-blind, randomized, placebo controlled studies in patients with chronic kidney disease stage 3 and 4 , found a reduction in proteinuria in $51 \%$ of paricalcitol patients versus $25 \%$ of placebo patients $(P<.01)$. The demonstration of a reduction in proteinuria associated with paricalcitol treatment, independent of concomitant use of agents that block the renin angiotensin system RAA, suggests that paricalcitol is a potential pharmacologic means of reducing proteinuria in chronic kidney disease. As a consequence, de Zeeuw et al. [44] designed a multinational, placebo-controlled, doubleblind trial (VITAL study): patients affected by type 2 diabetes and albuminuria receiving angiotensin-converting enzyme inhibitors or angiotensin receptor blockers were randomized to receive placebo, $1 \mu \mathrm{g} /$ day paricalcitol, or $2 \mu \mathrm{g} /$ day paricalcitol. They demonstrated that patients treated with $2 \mu \mathrm{g}$ of paricalcitol showed an early and sustained reduction in urinary albumin-to-creatinine ratio versus placebo $(P<.05)$. In another, smaller double-blind randomized study, Fishbane et al. [45] randomized 61 patients with estimated glomerular filtration rate from 15 to $90 \mathrm{~mL} / \mathrm{min} / 1.73 \mathrm{~m}^{2}$ and protein excretion greater than $400 \mathrm{mg} / 24 \mathrm{~h}$ to receive paricalcitol, $1 \mathrm{mcg} /$ day, or placebo: changes in protein excretion from baseline to last evaluation were $+2.9 \%$ for controls and $-17.6 \%$ for the paricalcitol group $(P<.05)$. Zhang et al. [46] studied streptozotocin- (STZ-) induced diabetic mice and discovered that treatment with losartan and paricalcitol completely prevented albuminuria, restored glomerular filtration barrier structure, and markedly reduced glomerulosclerosis, preventing renal injury in diabetic nephropathy. Thus, evidence is available suggesting that inhibition of the rennin angiotensin system with combination of vitamin $\mathrm{D}$ analogs and rennin angiotensin system inhibitors effectively prevents renal injury in diabetic nephropathy and it may be associated with improved renal protection.

\subsection{Renal Protection and Inhibition of the Renin-Angiotensin System (Table 11). Paricalcitol inhibits the rennin-angiot- ensin system. Freundlich et al. [47], in a study in remnant kidney model of chronic renal failure (5/6 nephrectomy) mice, administrated paricalcitol and found that paricalcitol decreases angiotensinogen, renin, renin receptor, and vascu- lar endothelial growth factor mRNA levels in the remnant kidney by $30-50$ percent versus untreated animals. Bodyak et al. [37] also found that paricalcitol significantly reduced cardiac renin expression in Dahl salt-sensitive rats.}

3.8. Renal Protection and Tubular Interstitial Fibrosis (Table 12). Tan et al. [48], using a mouse model of obstructive nephropathy, found that paricalcitol attenuates renal tubulo-interstitial fibrosis. Paricalcitol reduced infiltration of $\mathrm{T}$ cells and macrophages in the obstructed kidney and this inhibition of inflammatory cell infiltration was accompanied by a decreased expression of RANTES and TNF-alpha. Their results suggest that paricalcitol inhibits renal inflammatory infiltration and RANTES expression by promoting VDRmediated sequestration of NF-kappaB signaling. Wang et al. [49] treated with the VDR agonist doxercalciferol dietinduced obese mice, presenting proteinuria, renal mesangial expansion, accumulation of extracellular matrix proteins, and activation of oxidative stress. Treatment with doxercalciferol decreased proteinuria, podocyte injury, mesangial expansion, and extracellular matrix protein accumulation. The VDR agonist also decreased macrophage infiltration, oxidative stress, proinflammatory cytokines, and profibrotic growth factor. In addition, it prevented the activation of the renin-angiotensin-aldosterone system including the angiotensin II type 1 receptor and the mineralocorticoid 
TABLE 10: Renal protection and reduction of proteinuria.

\begin{tabular}{|c|c|c|c|}
\hline Author & Year & Study & Outcome \\
\hline Agarwal et al. [43] & 2005 & $\begin{array}{l}\text { Three RCTs in } 220 \text { CKD stage } 3 \text { and } 4 \\
\text { patients randomized to oral paricalcitol } \\
(N=107) \text { or placebo }(N=113), \\
\text { followed for up to } 24 \text { weeks }\end{array}$ & $\begin{array}{l}\text { Decreased proteinuria in } 29 / 57(51 \%) \text { of } \\
\text { paricalcitol patients versus } 15 / 61(25 \%) \\
\text { placebo patients, } P=.004 \text { (odds for } \\
\text { reduction in proteinuria } 3.2 \text { times greater } \\
\text { for paricalcitol patients) }\end{array}$ \\
\hline de Zeeuw et al. (VITAL study) [44] & 2010 & $\begin{array}{l}\text { Multinational RCT in } 281 \text { patients with } \\
\text { type } 2 \text { diabetes and albuminuria } \\
\text { receiving angiotensin-converting enzyme } \\
\text { inhibitors or angiotensin receptor } \\
\text { blockers were randomized to receive } \\
24 \text {-week treatment with placebo, } 1 \mu \mathrm{g} / \text { day } \\
\text { paricalcitol, or } 2 \mu \mathrm{g} \text { /day paricalcitol }\end{array}$ & $\begin{array}{l}\text { Patients on } 2 \mu \mathrm{g} \text { paricalcitol had an early, } \\
\text { sustained reduction in UACR (urinary } \\
\text { albumin-to-creatinine ratio), ranging } \\
\text { from }-18 \% \text { to }-28 \%(P=.014) \text { versus } \\
\text { placebo }\end{array}$ \\
\hline Fishbane et al. [45] & 2009 & $\begin{array}{l}\text { RCT of } 61 \text { patients with estimated } \\
\text { glomerular filtration rate from } 15 \text { to } \\
90 \mathrm{~mL} / \mathrm{min} / 1.73 \mathrm{~m}^{2} \text { and protein excretion } \\
\text { greater than } 400 \mathrm{mg} / 24 \text { h to receive } \\
\text { paricalcitol, } 1 \mathrm{mcg} / \text { day, or placebo. }\end{array}$ & $\begin{array}{l}\text { Changes in protein excretion from } \\
\text { baseline to last evaluation were }+2.9 \% \text { for } \\
\text { controls and }-17.6 \% \text { for the paricalcitol } \\
\text { group }(P<.05) \text {. }\end{array}$ \\
\hline Zhang et al. [46] & 2008 & $\begin{array}{l}\text { Study in streptozotocin- (STZ-) induced } \\
\text { diabetes model mice }\end{array}$ & $\begin{array}{l}\text { Treatment with losartan and paricalcitol } \\
\text { completely prevented albuminuria, } \\
\text { restored glomerular filtration barrier } \\
\text { structure, and markedly reduced } \\
\text { glomerulosclerosis, effectively preventing } \\
\text { renal injury in diabetic nephropathy }\end{array}$ \\
\hline
\end{tabular}

TABLE 11: Renal protection and inhibition of the rennin-angiotensin system.

\begin{tabular}{llll}
\hline Author & Year & Study & Outcome \\
\hline Freundlich et al. [47] & 2008 & $\begin{array}{l}\text { Study in remnant kidney model of chronic } \\
\text { renal failure (5/6 nephrectomy) mice, } \\
\text { administrating two different doses of } \\
\text { paricalcitol thrice weekly for 8 weeks. }\end{array}$ & $\begin{array}{l}\text { Paricalcitol was found to decrease } \\
\text { angiotensinogen, renin, renin receptor, and } \\
\text { vascular endothelial growth factor mRNA } \\
\text { levels in the remnant kidney by 30-50\% } \\
\text { compared to untreated animals. }\end{array}$ \\
\hline Bodyak et al. [37] & 2007 & $\begin{array}{l}\text { Study in Dahl salt-sensitive (DSS) rats. } \\
\text { Evaluation of the ability of paricalcitol to } \\
\text { attenuate the development of LV abnormalities. }\end{array}$ & $\begin{array}{l}\text { Paricalcitol significantly reduced cardiac } \\
\text { renin expression in DSS rats }\end{array}$ \\
\hline
\end{tabular}

receptor. An additional novel finding of this study is that the VDR activator decreased the accumulation of neutral lipids (triglycerides and cholesterol) and the expression of enzymes that mediate fatty acid and cholesterol synthesis.

3.9. Anti-Inflammatory Action (Table 13). In a pilot trial, Alborzi et al. [50] randomized patients in 3 groups receiving oral paricalcitol 0,1 , or $2 \mathrm{mcg} /$ day. They observed a reduction of high sensitivity C-reactive protein and of albuminuria in patients treated with paricalcitol, with a mechanism independent of its effects on hemodynamics or PTH suppression, as no differences were observed in iothalamate clearance, 24-hour ambulatory blood pressure, or PTH levels. Eleftheriadis et al. [51] also found that basal TNF-alpha concentration and basal IL-8 concentration were reduced by paricalcitol. These studies therefore suggest that paricalcitol also has immunomodulatory properties, another reason for administration of paricalcitol in patients with chronic renal failure. Indeed, patients with chronic kidney disease have chronic inflammation in the cardiovascular system and a reduced immunity to infections.

3.10. Endothelial Function (Table 14). VDR activators have been shown to modulate inflammation, thrombosis, and vasolidation, which are associated with endothelial dysfunction [55], and they have a potential for treatment of cardiovascular disease, including the improvement of endothelial dysfunction, which increases cardiovascular disease risk in chronic kidney disease [56]. Wu-Wong et al. [52] suggest that VDR activation improves endothelial function. They studied uremic rats (5/6 nephrectomized rat) and demonstrated that the uremia-impaired aortic relaxation was improved by paricalcitol (with a short duration of treatment, 2 weeks), in a dose-dependent manner, independent of serum PTH levels or blood pressure. PTH suppression alone did not improve endothelial function since in a separate experiment cinacalcet suppressed PTH without affecting endothelialdependent vasorelaxation. The role of phosphate in uremic 
TABLE 12: Renal protection and reduction of tubular interstitial fibrosis.

\begin{tabular}{|c|c|c|c|}
\hline Author & Year & Study & Outcome \\
\hline Tan et al. [48] & 2006 & $\begin{array}{l}\text { Study of the effects of paricalcitol in a mouse } \\
\text { model of obstructive nephropathy }\end{array}$ & $\begin{array}{l}\text { Paricalcitol reduced infiltration of T cells } \\
\text { and macrophages in the obstructed } \\
\text { kidney and this inhibition of } \\
\text { inflammatory cell infiltration was } \\
\text { accompanied by a decreased expression } \\
\text { of inflammatory cytokines. Paricalcitol } \\
\text { attenuates renal tubulo-interstitial } \\
\text { fibrosis in this animal model of renal } \\
\text { obstructive damage. }\end{array}$ \\
\hline Wang et al. [49] & 2011 & $\begin{array}{l}\text { Study in mice with diet-induced obesity, treated } \\
\text { with doxercalciferol. }\end{array}$ & $\begin{array}{l}\text { Doxercalciferol decreased proteinuria, } \\
\text { podocyte injury, mesangial expansion, } \\
\text { extracellular matrix protein } \\
\text { accumulation, macrophage infiltration, } \\
\text { oxidative stress, proinflammatory } \\
\text { cytokines, and profibrotic growth factor. } \\
\text { In addition, it prevented the activation of } \\
\text { the renin-angiotensin-aldosterone } \\
\text { system. VDR activation also decreased } \\
\text { the accumulation of neutral lipids } \\
\text { (triglycerides and cholesterol) and the } \\
\text { expression of enzymes that mediate fatty } \\
\text { acid and cholesterol synthesis. }\end{array}$ \\
\hline
\end{tabular}

TABLE 13: Anti-inflammatory action.

\begin{tabular}{|c|c|c|c|}
\hline Author & Year & Study & Outcome \\
\hline Alborzi et al. [50] & 2008 & $\begin{array}{l}\text { A pilot trial in } 24 \text { patients randomized to } 3 \\
\text { groups to receive } 0,1 \text {, or } 2 \text { mcg of } \\
\text { paricalcitol orally for } 1 \text { month. }\end{array}$ & $\begin{array}{l}\text { At } 1 \text { month, the treatment/baseline ratio of high } \\
\text { sensitivity C-reactive protein was } 1.5 \text { ( } 95 \% \text { CI: } 1.1 \text { to } \\
2.1 ; P<.05) \text { with placebo, } 0.8 \text { ( } 95 \% \text { CI: } 0.3 \text { to } 1.9 ; \\
P=.62) \text { with the } 1 \text { mcg dose, and } 0.5 \text { ( } 95 \% \text { CI: } 0.3 \text { to } \\
0.9 ; P<.05) \text { with a } 2 \text { mcg dose of paricalcitol. The } \\
\text { treatment/baseline ratio of } 24 \text {-hour albumin excretion } \\
\text { rate was } 1.35 \text { ( } 95 \% \text { CI: } 1.08 \text { to } 1.69 ; P=.01) \text { with } \\
\text { placebo, } 0.52(95 \% \text { CI: } 0.40 \text { to } 0.69 ; P<.001) \text { with a } \\
1 \text {-mcg dose, and } 0.54(95 \% \text { CI: } 0.35 \text { to } 0.83 ; P=.01) \\
\text { with a } 2 \text { mcg dose }(P<.001 \text { between group changes). }\end{array}$ \\
\hline Eleftheriadis et al. [51] & 2010 & $\begin{array}{l}\text { A study in } 10 \text { healthy volunteers; peripheral } \\
\text { blood mononuclear cells (PBMC) were } \\
\text { cultured for } 48 \text { hours in presence or not of } \\
\text { lipopolysaccharide (LPS) and in the } \\
\text { presence or not of paricalcitol. TNF-alpha } \\
\text { and IL- } 8 \text { produced by PBMC were } \\
\text { measured. }\end{array}$ & $\begin{array}{l}\text { Basal TNF-alpha concentration and IL- } 8 \\
\text { concentrations were reduced by paricalcitol. } \\
\text { Paricalcitol also blunted the TNF-alpha concentration } \\
\text { increase induced by LPS. Paricalcitol reduced to its } \\
\text { basal level the IL- } 8 \text { concentration increase by LPS. The } \\
\text { in vitro inhibition of TGF-alpha and IL- } 8 \text { by } \\
\text { paricalcitol confirms the immunomodulatory } \\
\text { properties of this vitamin D analogue. }\end{array}$ \\
\hline
\end{tabular}

TABLE 14: Endothelial function.

\begin{tabular}{llll}
\hline Author & Year & Study & Outcome \\
\hline Wu-Wong et al. [52] & 2010 & $\begin{array}{l}\text { Study in uremic rats }(5 / 6 \mathrm{NX} \text { rats), } \\
\text { treated for two weeks with paricalcitol. }\end{array}$ & $\begin{array}{l}\text { Uremia impaired aortic relaxation was improved } \\
\text { by paricalcitol in a dose-dependent manner, } \\
\text { independent of serum PTH levels or blood } \\
\text { pressure. PTH suppression alone did not improve } \\
\text { endothelial function since in a separate } \\
\text { experiment cinacalcet suppressed PTH without } \\
\text { affecting endothelial-dependent vasorelaxation. }\end{array}$ \\
\hline Karavalakis et al. [53] 2008 & $\begin{array}{l}\text { Uremic }(5 / 6 \mathrm{NX}) \text { rats treated with } \\
\text { paricalcitol }(0.2 \mathrm{mcg} / \mathrm{kg} \text {, thrice weekly) } \\
\text { for 12 weeks. Aortic histology was studied }\end{array}$ & $\begin{array}{l}\text { Paricalcitol treatment showed both benefits and } \\
\text { harmful effects: vasoconstriction was reduced but } \\
\text { calcification increased. Plasma phosphate was } \\
\text { increased, 2.1- to 2.5-fold higher than normal. }\end{array}$ \\
\hline
\end{tabular}


subjects is important to consider. In the study by $\mathrm{Wu}$ Wong et al. [52] uremic rats had normal serum phosphate levels. In a previous study, Karavalakis et al. [53] reported that, in the 5/6 nephrectomized rats fed a special diet that induced severe hyperphosphatemia, paricalcitol at $0.2 \mu \mathrm{g} / \mathrm{kg}$ reduced vasoconstriction but increased vascular calcification.

The improvement of endothelial function by VDR activators may be one of the mechanisms responsible for the cardiovascular benefit associated with these agents in chronic kidney disease.

\section{Acknowledgment}

L. Gravellone and M. A. Rizzo contributed equally to the preparation of this paper.

\section{References}

[1] A. S. Go, G. M. Chertow, D. Fan, C. E. McCulloch, and C. Y. Hsu, "Chronic kidney disease and the risks of death, cardiovascular events, and hospitalization," New England Journal of Medicine, vol. 351, no. 13, pp. 1296-1305, 2004.

[2] M. J. Sarnak, B. E. Coronado, T. Greene et al., "Cardiovascular disease risk factors in chronic renal insufficiency," Clinical Nephrology, vol. 57, no. 5, pp. 327-335, 2002.

[3] R. Vanholder, Z. Massy, A. Argiles et al., "Chronic kidney disease as cause of cardiovascular morbidity and mortality," Nephrology Dialysis Transplantation, vol. 20, pp. 1048-1056, 2005.

[4] G. A. Block, T. E. Hulbert-Shearon, N. W. Levin, and F. K. Port, "Association of serum phosphorus and calcium x phosphate product with mortality risk in chronic hemodialysis patients: a national study," American Journal of Kidney Diseases, vol. 31, no. 4, pp. 607-617, 1998.

[5] M. Teng, M. Wolf, M. N. Ofsthun et al., "Activated injectable vitamin D and hemodialysis survival: a historical cohort study," Journal of the American Society of Nephrology, vol. 16, no. 4, pp. 1115-1125, 2005.

[6] F. Llach and F. Velasquez Forero, "Secondary hyperparathyroidism in chronic renal failure: pathogenic and clinical aspects," American Journal of Kidney Diseases, vol. 38, no. 5, supplement 5, pp. S20-S33, 2001.

[7] G. A. Block, P. S. Klassen, J. M. Lazarus, N. Ofsthun, E. G. Lowrie, and G. M. Chertow, "Mineral metabolism, mortality, and morbidity in maintenance hemodialysis," Journal of the American Society of Nephrology, vol. 15, no. 8, pp. 2208-2218, 2004.

[8] D. L. Andress, "Vitamin D in chronic kidney disease: a systemic role for selective vitamin D receptor activation," Kidney International, vol. 69, no. 1, pp. 33-43, 2006.

[9] R. J. Lund, D. L. Andress, M. Amdahl, L. A. Williams, and R. P. Heaney, "Differential effects of paricalcitol and calcitriol on intestinal calcium absorption in hemodialysis patients," American Journal of Nephrology, vol. 31, no. 2, pp. 165-170, 2010.

[10] L. A. Greenbaum, N. Benador, S. L. Goldstein et al., "Intravenous paricalcitol for treatment of secondary hyperparathyroidism in children on hemodialysis," American Journal of Nephrology, vol. 28, no. 1, pp. 97-106, 2008.

[11] D. Coyne, M. Acharya, P. Qiu et al., "Paricalcitol capsule for the treatment of secondary hyperparathyroidism in stages 3 and 4 CKD," American Journal of Kidney Diseases, vol. 47, no. 2, pp. 263-276, 2006.

[12] K. J. Martin, E. A. González, M. Gellens, L. L. Hamm, H. Abboud, and J. Lindberg, "19-nor-1- $\alpha$-25-dihydroxyvitamin D (paricalcitol) safely and effectively reduces the levels of intact parathyroid hormone in patients on hemodialysis," Journal of the American Society of Nephrology, vol. 9, no. 8, pp. 1427-1432, 1998.

[13] J. Lindberg, K. J. Martin, E. A. González, S. R. Acchiardo, J. R. Valdin, and C. Soltanek, "A long-term, multicenter study of the efficacy and safety of paricalcitol in end-stage renal disease," Clinical Nephrology, vol. 56, no. 4, pp. 315-323, 2001.

[14] S. M. Sprague, F. Llach, M. Amdahl, C. Taccetta, and D. Batlle, "Paricalcitol versus calcitriol in the treatment of secondary hyperparathyroidism," Kidney International, vol. 63, no. 4, pp. 1483-1490, 2003.

[15] N. Mittman, R. Khana, S. Rani et al., "Comparison of paricalcitol and calcitriol therapy for the treatment of secondary hyperparathyroidism in patients on maintenance dialysis," in Proceedings of the American Society of Nephrology Renal Week Conference, St. Louis, Mo, USA, October-November 2004.

[16] D. W. Coyne, M. Grieff, S. N. Ahya, K. Giles, K. Norwood, and E. Slatopolsky, "Differential effects of acute administration of 19-nor-1,25-dihydroxy-vitamin $\mathrm{D}$ and 1,25-dihydroxyvitamin D on serum calcium and phosphorus in hemodialysis patients," American Journal of Kidney Diseases, vol. 40, no. 6, pp. 1283-1288, 2002.

[17] R. J. Lund, D. L. Andress, M. Amdahl, L. A. Williams, and R. P. Heaney, "Differential effects of paricalcitol and calcitriol on intestinal calcium absorption in hemodialysis patients," American Journal of Nephrology, vol. 31, no. 2, pp. 165-170, 2010.

[18] N. Mittman, B. Desiraju, K. B. Meyer, J. Chattopadhyay, and M. M. Avram, "Treatment of secondary hyperparathyroidism in ESRD: a 2-year, single-center crossover study," Kidney International Supplement, no. 117, pp. S33-S36, 2010.

[19] H. E. Joist, S. N. Ahya, K. Giles, K. Norwood, E. Slatopolsky, and D. W. Coyne, "Differential effects of very high doses of doxercalciferol and paricalcitol on serum phosphorus in hemodialysis patients," Clinical Nephrology, vol. 65, no. 5, pp. 335-341, 2006.

[20] J. M. Frazão, L. Elangovan, H. M. Maung et al., "Intermittent doxercalciferol ( $1 \alpha$-hydroxyvitamin d) therapy for secondary hyperparathyroidism," American Journal of Kidney Diseases, vol. 36, no. 3, pp. 550-561, 2000.

[21] J. W. Coburn, H. M. Maung, L. Elangovan et al., "Doxercalciferol safely suppresses PTH levels in patients with secondary hyperparathyroidism associated with chronic kidney disease stages 3 and 4," American Journal of Kidney Diseases, vol. 43, no. 5, pp. 877-890, 2004.

[22] A. L. Zisman, W. Ghantous, P. Schinleber, L. Roberts, and S. M. Sprague, "Inhibition of parathyroid hormone: a dose equivalency study of paricalcitol and doxercalciferol," American Journal of Nephrology, vol. 25, no. 6, pp. 591-595, 2005.

[23] M. Hayashi, Y. Tsuchiya, Y. Itaya et al., "Comparison of the effects calcitriol and maxacalcitol on secondary hyperparathyroidism in patients on chronic haemodialysis: a randomized propective multicenter trial," Nephrology Dialysis Transplantation, vol. 19, no. 8, pp. 2067-2073, 2004.

[24] K. Shiizaki, S. Negi, I. Hatamura et al., "Biochemical and cellular effects of direct maxacalcitol injection into parathyroid gland in uremic rats," Journal of the American Society of Nephrology, vol. 16, no. 1, pp. 97-108, 2005. 
[25] J. J. Kazama, H. Maruyama, I. Narita, and F. Gejyo, "Maxacalcitol is a possible less phosphatemic vitamin D analog," Therapeutic Apheresis and Dialysis, vol. 9, no. 4, pp. 352-354, 2005.

[26] Y. Oyama, J. J. Kazama, K. Omori et al., "Pretreatment plasma intact parathyroid hormone and serum calcium levels, but not serum phosphate levels, predict the response to maxacalcitol therapy in dialysis patients with secondary hyperparathyroidism," Clinical and Experimental Nephrology, vol. 9, no. 2, pp. 142-147, 2005.

[27] S. Okuno, E. Ishimura, K. Kitatani et al., "Relationship between parathyroid gland size and responsiveness to maxacalcitol therapy in patients with secodary hyperparathyroidism," Nephrology Dialysis Transplantation, vol. 18, no. 12, pp. 2613-2621, 2003.

[28] K. Shiizaki, I. Hatamura, S. Negi et al., "Percutaneous maxacalcitol injection therapy regresses hyperplasia of parathyroid and induces apoptosis in uremia," Kidney International, vol. 64, no. 3, pp. 992-1003, 2003.

[29] T. Akizawa and K. Kurokawa, "Long-term clinical effect of maxacalcitol on hemodialysis patients with secondary hyperparathyroidism," Clinical Calcium, vol. 12, no. 6, pp. 781-788, 2002.

[30] A. Saito, Y. Matsumoto, Y. Oyama, M. Asaka, and H. Yokoyama, "Effectiveness of weekly percutaneous maxacalcitol injection therapy in patients with secondary hyperparathyroidism," Therapeutic Apheresis and Dialysis, vol. 14, no. 1, pp. 98-103, 2010.

[31] E. Slatopolsky, M. Cozzolino, Y. Lu et al., "Efficacy of 19Nor-1,25-(OH)2D2 in the prevention and treatment of hyperparathyroid bone disease in experimental uremia," Kidney International, vol. 63, no. 6, pp. 2020-2027, 2003.

[32] J. J. Kazama, K. Omori, N. Takahashi et al., "Maxacalcitol therapy decreases circulating osteoprotegerin levels in dialysis patients with secondary hyperparathyroidism," Clinical Nephrology, vol. 64, no. 1, pp. 64-68, 2005.

[33] D. G. Dobrez, A. Mathes, M. Amdahl, S. E. Marx, J. Z. Melnick, and S. M. Sprague, "Paricalcitol-treated patients experience improved hospitalization outcomes compared with calcitrioltreated patients in real-world clinical settings," Nephrology Dialysis Transplantation, vol. 19, no. 5, pp. 1174-1181, 2004.

[34] M. G. Vervloet and J. W.R. Twisk, "Mortality reduction by vitamin $\mathrm{D}$ receptor activation in end-stage renal disease: a commentary on the robustness of current data," Nephrology Dialysis Transplantation, vol. 24, no. 3, pp. 703-706, 2009.

[35] M. Teng, M. Wolf, E. Lowrie, N. Ofsthun, J. M. Lazarus, and R. Thadhani, "Survival of patients undergoing hemodialysis with paricalcitol or calcitriol therapy," New England Journal of Medicine, vol. 349, no. 5, pp. 446-456, 2003.

[36] F. Tentori, W. C. Hunt, C. A. Stidley et al., "Mortality risk among hemodialysis patients receiving different vitamin D analogs," Kidney International, vol. 70, no. 10, pp. 1858-1865, 2006.

[37] N. Bodyak, J. C. Ayus, S. Achinger et al., "Activated vitamin $\mathrm{D}$ attenuates left ventricular abnormalities induced by dietary sodium in Dahl salt-sensitive animals," Proceedings of the National Academy of Sciences of the United States of America, vol. 104, no. 43, pp. 16810-16815, 2007.

[38] W. Xiang, J. Kong, S. Chen et al., "Cardiac hypertrophy in vitamin D receptor knockout mice: role of the systemic and cardiac renin-angiotensin systems," American Journal of Physiology, vol. 288, no. 1, pp. E125-E132, 2005.
[39] C. Zhou, F. Lu, K. Cao, DI. Xu, D. Goltzman, and D. Miao, "Calcium-independent and 1,25(OH)2D3-dependent regulation of the renin-angiotensin system in 1alpha-hydroxylase knockout mice," Kidney International, vol. 74, no. 2, pp. 170$179,2008$.

[40] The PRIMO Study_Paricalcitol Capsules Benefits in Renal Failure Induced Cardiac Morbidity in Chronic Kidney Disease Stage 3 and 4 (ongoing), http://clinicaltrials.gov/ct2/show/ NCT00497146.

[41] M. Mizobuchi, J. L. Finch, D. R. Martin, and E. Slatopolsky, "Differential effects of vitamin D receptor activators on vascular calcification in uremic rats," Kidney International, vol. 72, no. 6, pp. 709-715, 2007.

[42] K. Husain, E. Suarez, A. Isidro, and L. Ferder, "Effects of paricalcitol and enalapril on atherosclerotic injury in mouse aortas," American Journal of Nephrology, vol. 32, no. 4, pp. 296304, 2010.

[43] R. Agarwal, M. Acharya, J. Tian et al., "Antiproteinuric effect of oral paricalcitol in chronic kidney disease," Kidney International, vol. 68, no. 6, pp. 2823-2828, 2005.

[44] D. De Zeeuw, R. Agarwal, M. Amdahl et al., "Selective vitamin $\mathrm{D}$ receptor activation with paricalcitol for reduction of albuminuria in patients with type 2 diabetes (VITAL study): a randomised controlled trial," The Lancet, vol. 376, no. 9752, pp. 1543-1551, 2010.

[45] S. Fishbane, H. Chittineni, M. Packman, P. Dutka, N. Ali, and N. Durie, "Oral paricalcitol in the treatment of patients with CKD and proteinuria: a randomized trial," American Journal of Kidney Diseases, vol. 54, no. 4, pp. 647-652, 2009.

[46] Z. Zhang, Y. Zhang, G. Ning, D. K. Deb, J. Kong, and C. L. Yan, "Combination therapy with AT1 blocker and vitamin D analog markedly ameliorates diabetic nephropathy: blockade of compensatory renin increase," Proceedings of the National Academy of Sciences of the United States of America, vol. 105, no. 41, pp. 15896-15901, 2008.

[47] M. Freundlich, Y. Quiroz, Z. Zhang et al., "Suppression of renin-angiotensin gene expression in the kidney by paricalcitol," Kidney International, vol. 74, no. 11, pp. 1394-1402, 2008.

[48] X. Tan, X. Wen, and Y. Liu, "Paricalcitol inhibits renal inflammation by promoting vitamin $\mathrm{D}$ receptor-mediated sequestration of NF- $\kappa \mathrm{B}$ signaling," Journal of the American Society of Nephrology, vol. 19, no. 9, pp. 1741-1752, 2008.

[49] X. X. Wang, T. Jiang, Y. Shen et al., "Vitamin D receptor agonist doxercalciferol modulates dietary fat-induced renal disease and renal lipid metabolism," American Journal of Physiology, vol. 300, no. 3, pp. F801-F810, 2011.

[50] P. Alborzi, N. A. Patel, C. Peterson et al., "Paricalcitol reduces albuminuria and inflammation in chronic kidney disease a randomized double-blind pilot trial," Hypertension, vol. 52, no. 2, pp. 249-255, 2008.

[51] T. Eleftheriadis, G. Antoniadi, V. Liakopoulos, C. Kartsios, I. Stefanidis, and G. Galaktidou, "Paricalcitol reduces basal and lipopolysaccharide-induced (LPS) TNF- $\alpha$ and IL-8 production by human peripheral blood mononuclear cells," International Urology and Nephrology, vol. 42, no. 1, pp. 181185, 2010.

[52] J. R. Wu-Wong, W. Noonan, M. Nakane et al., "Vitamin $\mathrm{D}$ receptor activation mitigates the impact of uremia on endothelial function in the 5/6 nephrectomized rats," International Journal of Endocrinology, vol. 2010, Article ID 625852, 2010. 
[53] E. Karavalakis, A. Eräranta, T. I. Vehmas et al., "Paricalcitol treatment and arterial tone in experimental renal insufficiency," Nephron Experimental Nephrology, vol. 109, no. 3, pp. e84-e93, 2008.

[54] A. Levin and Y. C. Li, "Vitamin D and its analogues: do they protect against cardiovascular disease in patients with kidney disease?" Kidney International, vol. 68, no. 5, pp. 1973-1981, 2005.

[55] R. Ebert, N. Schütze, J. Adamski, and F. Jakob, "Vitamin $\mathrm{D}$ signaling is modulated on multiple levels in health and disease," Molecular and Cellular Endocrinology, vol. 248, no. 12, pp. 149-159, 2006.

[56] J. R. Wu-Wong, "Potential for vitamin D receptor agonists in the treatment of cardiovascular disease," British Journal of Pharmacology, vol. 158, no. 2, pp. 395-412, 2009. 


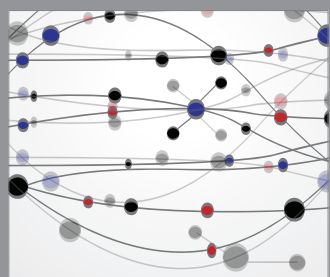

The Scientific World Journal
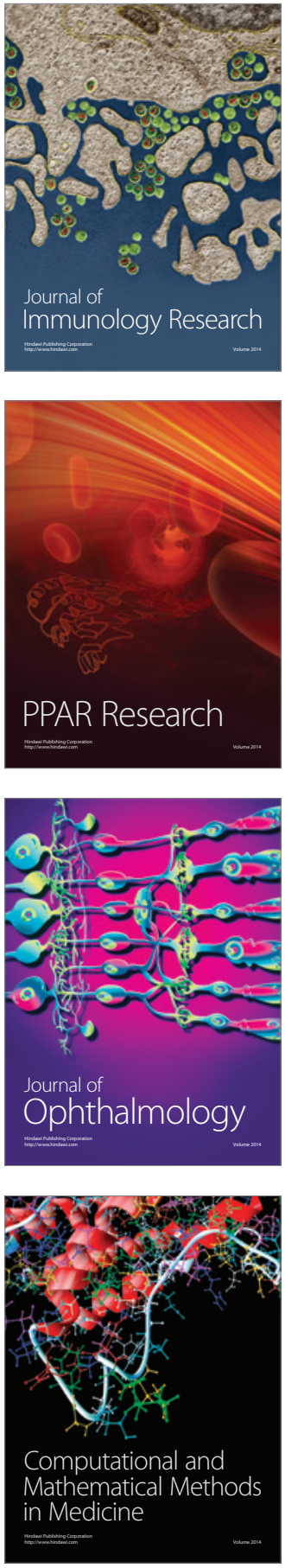

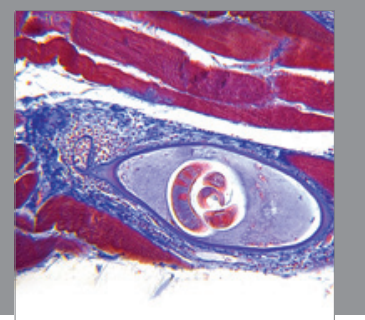

Gastroenterology

Research and Practice
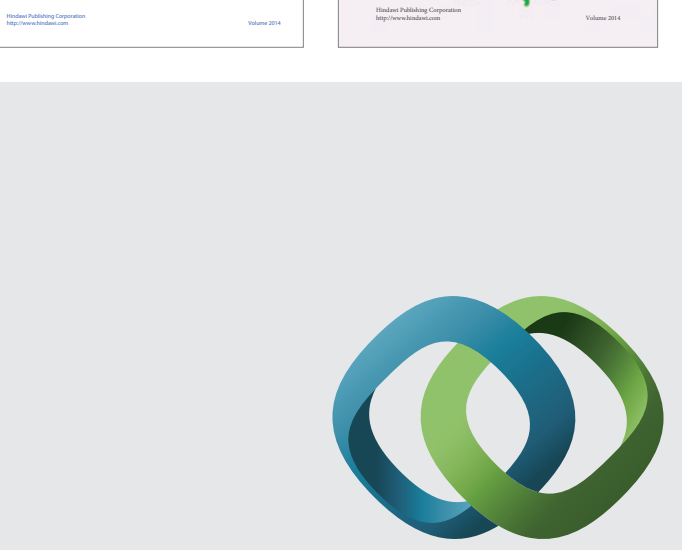

\section{Hindawi}

Submit your manuscripts at

http://www.hindawi.com
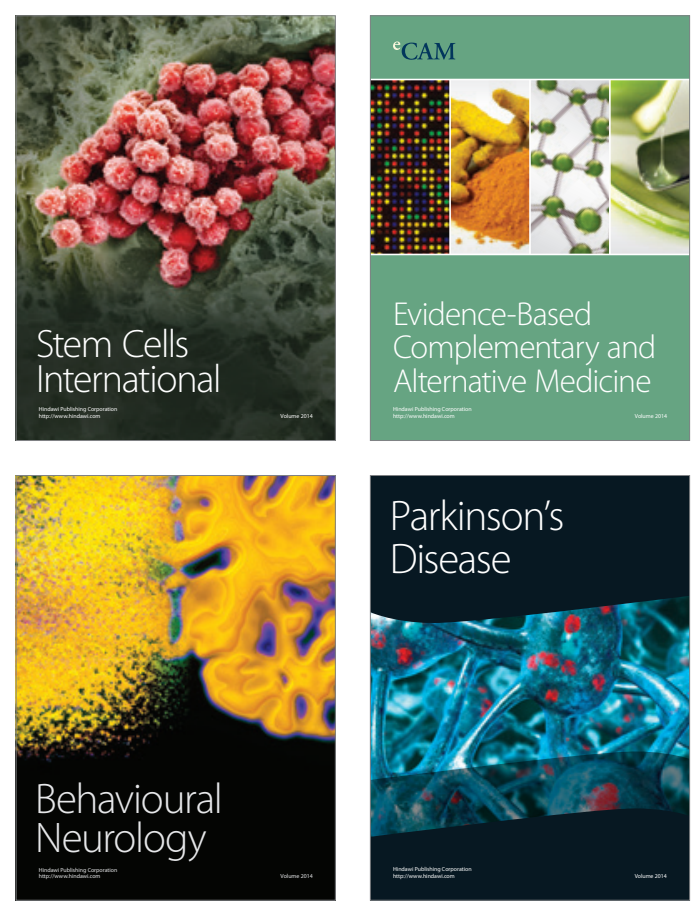

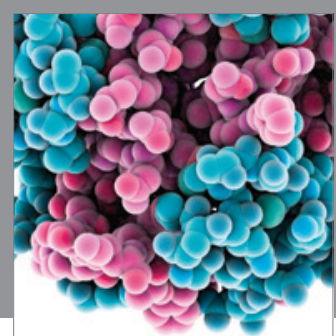

Journal of
Diabetes Research

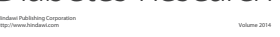

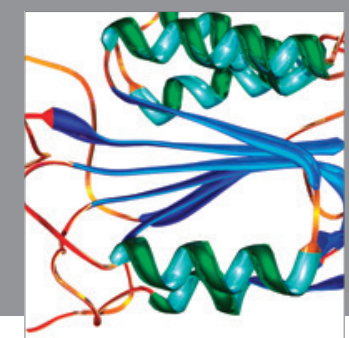

Disease Markers
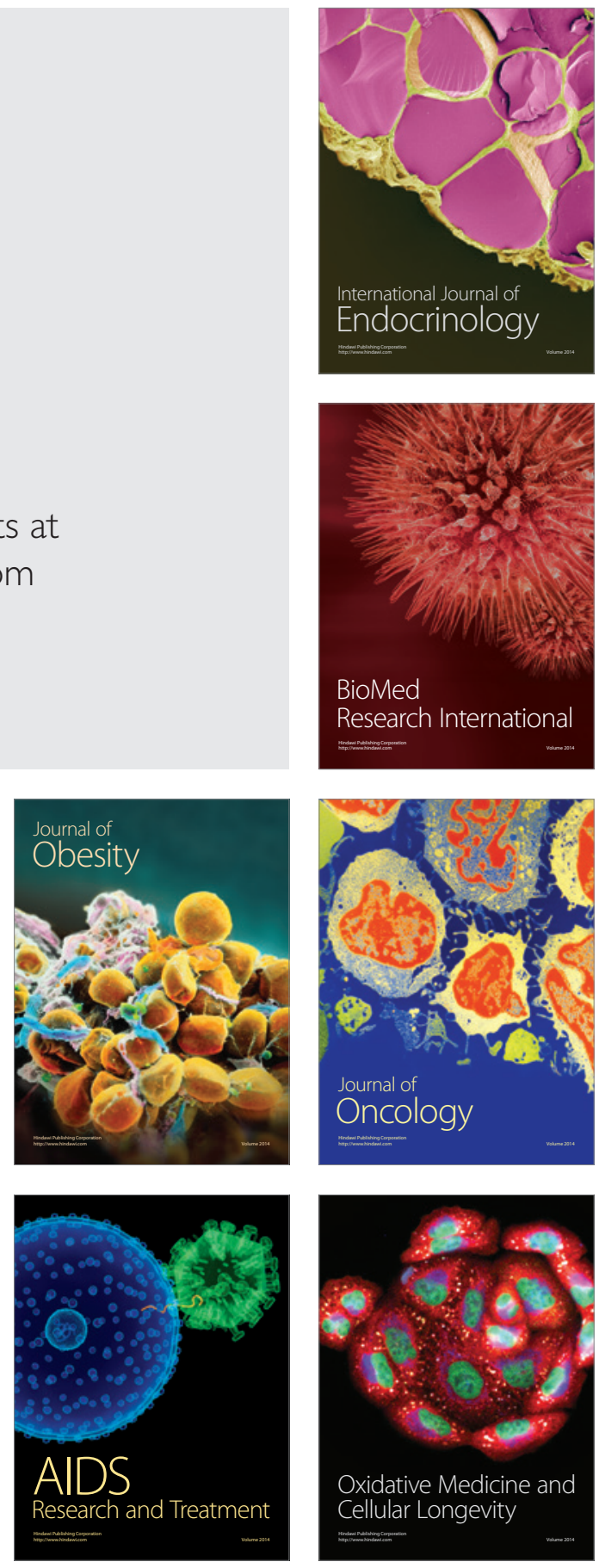